\title{
Necrotic cell-derived high mobility group box 1 attracts antigen-presenting cells but inhibits hepatocyte growth factor-mediated tropism of mesenchymal stem cells for apoptotic cell death
}

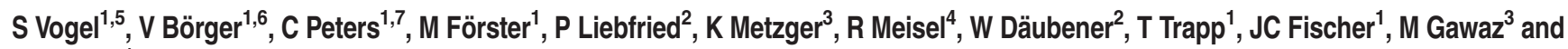 \\ RV Sorg*,1
}

Tissue damage due to apoptotic or necrotic cell death typically initiates distinct cellular responses, leading either directly to tissue repair and regeneration or to immunological processes first, to clear the site, for example, of potentially damage-inducing agents. Mesenchymal stem cells (MSC) as well as immature dendritic cells (iDC) and monocytes migrate to injured tissues. MSC have regenerative capacity, whereas monocytes and iDC have a critical role in inflammation and induction of immune responses, including autoimmunity after tissue damage. Here, we investigated the influence of apoptotic and necrotic cell death on recruitment of MSC, monocytes and IDC, and identified hepatocyte growth factor (HGF) and the alarmin high mobility group box 1 (HMGB1) as key factors differentially regulating these migratory responses. MSC, but not monocytes or iDC, were attracted by apoptotic cardiomyocytic and neuronal cells, whereas necrosis induced migration of monocytes and iDC, but not of MSC. Only apoptotic cell death resulted in HGF production and HGF-mediated migration of MSC towards the apoptotic targets. In contrast, HMGB1 was predominantly released by the necrotic cells and mediated recruitment of monocytes and iDC via the receptor of advanced glycation end products. Moreover, necrotic cardiomyocytic and neuronal cells caused an HMGB1/toll-like receptor-4dependent inhibition of MSC migration towards apoptosis or HGF, while recruitment of monocytes and iDC by necrosis or HMGB1 was not affected by apoptotic cells or HGF. Thus, the type of cell death differentially regulates recruitment of either MSC or monocytes and iDC through HGF and HMGB1, respectively, with a dominant, HMGB1-mediated role of necrosis in determining tropism after tissue injury.

Cell Death and Differentiation (2015) 22, 1219-1230; doi:10.1038/cdd.2014.225; published online 9 January 2015

Cell death may be part of a physiological process, which typically initiates tissue repair and regeneration while maintaining immunological tolerance, partially because apoptotic cells are removed from the tissue and circulation. ${ }^{1}$ On the other hand, cell death may also be the result of an insult and requires activation of the immune system not only to clear the necrotic debris but also to mount an immune response against the potentially tissue-damaging agent, prior to tissue repair and regeneration. Thus, depending on the type of cell death, distinct programs have to be coordinately activated including release of chemoattractive factors by the dying cells that induce and regulate recruitment of distinct cell populations including macrophages, immature dendritic cells (iDC) and stem cells.
Hepatocyte growth factor (HGF) and high mobility group box 1 (HMGB1) have been reported to be released by damaged cells. HGF is a pleiotropic cytokine ${ }^{2}$ that is produced and proteolytically activated during tissue damage, ${ }^{3,4}$ including ischemia of the heart ${ }^{5}$ and brain. ${ }^{6}$ It exerts its effects via interaction with the MET receptor. ${ }^{7}$ Recently, we could demonstrate that only apoptotic, but neither necrotic nor vital cardiomyocytic and neuronal cells produce biologically active HGF. $^{8,9}$ It is cardioprotective and neuroprotective and contributes to tissue regeneration in other organs as well, partially due to anti-apoptotic, pro-angiogenic and mitogenic activities. ${ }^{2,10-12}$ Moreover, HGF attracts stem and progenitor cells, including cardiac stem cells, ${ }^{13}$ neuronal stem cells, ${ }^{14}$ endothelial progenitor cells ${ }^{15}$ and mesenchymal stem cells

\footnotetext{
${ }^{1}$ Institute for Transplantation Diagnostics and Cell Therapeutics, Heinrich Heine University Hospital, Düsseldorf, Germany; ${ }^{2}$ Institute of Medical Microbiology and Hospital Hygiene, Heinrich Heine University Hospital, Düsseldorf, Germany; ${ }^{3}$ Department of Cardiology and Cardiovascular Diseases, Eberhard Karls University, Tübingen, Germany and ${ }^{4}$ Clinic of Pediatric Oncology, Hematology and Clinical Immunology, Heinrich Heine University Hospital, Düsseldorf, Germany

${ }^{*}$ Corresponding author: RV Sorg, Institute for Transplantation Diagnostics and Cell Therapeutics, Heinrich Heine University Hospital, Moorenstrasse 5, Building 14.80, 40225 Düsseldorf, Germany. Tel: +49 21181 04330; Fax: +49 21181 04340; E-mail: Ruediger.Sorg@ @med.uni-duesseldorf.de

${ }^{5}$ Current address: Department of Cardiology and Cardiovascular Diseases, Eberhard Karls University, Tübingen, Germany

${ }^{6}$ Current address: Institute for Transfusion Medicine, University Hospital Essen, Essen, Germany

${ }^{7}$ Current address: Department of Neurology, Heinrich Heine University Hospital, Düsseldorf, Germany

Abbreviations: BM, bone marrow; BSA, bovine serum albumin; CCR7, C-C chemokine receptor type 7; CM, conditioned medium; CXCL12, chemokine C-X-C motif ligand 12; CXCR4, C-X-C chemokine receptor type 4; DMEM, Dulbecco's modified Eagle's medium; ELISA, enzyme-linked immunosorbent assay; FCS, fetal calf serum; HGF, hepatocyte growth factor; HMGB1, high mobility group box 1; iDC, immature dendritic cell(s); MSC, mesenchymal stem cell(s); PARP-1, poly (ADP-ribose) polymerase-1; PBS, phosphate-buffered saline; RAGE, receptor of advanced glycation end products; TLR-2, toll-like receptor-2; TLR-4, toll-like receptor 4

Received 26.3.14; revised 22.11.14; accepted 24.11.14; Edited by G Kroemer; published online 09.1.15
} 
(MSC), ${ }^{4,9}$ which probably contributes to its tissue protective and regenerative effects.

MSC, which are also referred to as mesenchymal stromal cells, are multipotent non-hematopoietic stem cells, which are able to differentiate at least along osteogenic, chondrogenic and adipogenic pathways. ${ }^{16}$ Initially identified in bone marrow (BM), MSC or MSC-like cells have meanwhile been described in most tissues. They are recruited to sites of tissue damage, have beneficial effects on tissue regeneration, for example, after myocardial infarction or stroke, ${ }^{17,18}$ and thus may serve as a regenerative reservoir. Although the mechanisms are still a matter of debate, paracrine effects via secretion of a vast array of chemokines, cytokines, growth factors and other factors affecting angiogenesis, apoptosis, migration, proliferation, differentiation and extracellular matrix remodeling appear to have a central role, whereas direct tissue replacement by local engraftment and differentiation or even transdifferentiation of MSC seem uncommon. ${ }^{19}$ In addition, $\mathrm{MSC}^{20,21}$ like $\mathrm{HGF}^{2}$ exert immunosuppressive activities, modulating $\mathrm{DC}$ as well as T-cell activation and function. Therefore, HGF and MSC may not only contribute to tissue regeneration after apoptotic cell death, but also to maintaining immunological tolerance.

HMGB1 is a highly conserved, non-histone, architectural DNA-binding protein, which is involved in DNA replication, recombination, repair and transcription. ${ }^{22}$ It can be actively secreted by monocytes/macrophages, DC and other cells in response to pathogen-derived, pro-inflammatory or stress signals. ${ }^{23-25}$ Moreover, HMGB1 is a prototypic damageassociated molecular pattern passively released from necrotic cells. ${ }^{26}$ Although it may be released from apoptotic cells as well, ${ }^{27}$ it appears to be preferentially retained in apoptotic bodies because of enhanced chromatin binding ${ }^{26}$ and to be inactive due to oxidization of the crucial cysteine residues 23 , 45 and $106,{ }^{28,29}$ which is critical for the tolerogenic nature of apoptotic cell death. Either secreted or passively released from necrotic cells, HMGB1 exerts its effects via the receptor of advanced glycation end products (RAGE) ${ }^{30}$ and the tolllike receptors TLR-2 and TLR- $4,{ }^{31}$ and may form complexes with chemokines-such as chemokine C-X-C motif ligand 12 (CXCL12), enhancing their activity. ${ }^{32}$ It recruits monocytes/ macrophages and DC to sites of tissue damage or infection and causes their activation, thereby mediating sterile, tissueinjury-driven as well as pathogen-driven inflammation and the initiation of adaptive immune responses. ${ }^{25,33}$ Although the inflammatory processes initiated by HMGB1 appear to be detrimental to tissue regeneration, ${ }^{25,34}$ pro-angiogenic activities of HMGB1 $1^{35}$ as well as recruitment of stem and progenitor cells ${ }^{36,37}$ may have beneficial effects after tissue damage.

Thus, HGF and HMGB1 appear to be key factors released in the context of apoptosis and necrosis, respectively, which contribute to regenerative or inflammatory and immunological responses after tissue damage. In this study, we have examined the consequences of apoptosis and necrosis of cardiomyocytic and neuronal cells for the recruitment of MSC, monocytes and $\mathrm{iDC}$ and the respective roles of HGF and HMGB1. We could identify a differential release of HGF and HMGB1 and differential migratory responses of stem and antigen-presenting cells, depending on the type of cell death.
Moreover, an HMGB1-mediated dominant role of necrosis over apoptosis for such cellular tropisms after tissue cell death could be identified.

\section{Results}

Apoptotic neuronal and cardiac cells attract MSC, whereas necrotic cells are targets for monocytes and iDC. An under-agarose chemotaxis assay was used to investigate the target-directed migration of MSC, monocytes and iDC towards vital (untreated), apoptotic (staurosporine or sodium azide treated) and necrotic $\left(\mathrm{H}_{2} \mathrm{O}_{2}\right.$ or ethanol treated) HT-22 hippocampal neurons and $\mathrm{HL}-1$ cardiomyocytes. Conditioned medium (CM) derived from apoptotic but not necrotic HT-22 (Figure 1a) and HL-1 cells (Figure 1b) attracted MSC. In contrast, necrotic but not apoptotic cell death constituted a chemoattractive stimulus for monocytes (Figures 1c and d) and iDC (Figures 1e and f). CM derived from vital neuronal or cardiac cells stimulated migration of neither of the three cell populations (Figures 1a-f). Comparable results have been obtained when a modified Boyden chamber assay was used to detect cell recruitment; MSC migrated towards apoptotic cells, whereas monocytes towards necrotic cells (Supplementary Figure S1).

Apoptosis of neuronal and cardiac cells is associated with secretion of HGF, whereas necrosis results in release of HMGB1. To analyze the molecular mechanisms underlying migration of MSC, monocytes and iDC towards apoptotic or necrotic cell death, the presence of two candidate factors, HGF and HMGB1, was determined in the conditioned media by enzyme-linked immunosorbent assay (ELISA; Figure 2a). Significant amounts of HGF were detected only in $\mathrm{CM}$ derived from apoptotic cells, whereas levels of HMGB1, which was present at low levels after induction of apoptosis, were significantly higher in $\mathrm{CM}$ derived from necrotic HT-22 and HL-1 cells $(P \leq 0.0001$ for either combination). Both factors were absent or present only at very low concentrations in $\mathrm{CM}$ of vital cells.

To further confirm this observation, immunofluorescence staining for HGF and HMGB1 in vital, apoptotic (staurosporine treated) and necrotic $\left(\mathrm{H}_{2} \mathrm{O}_{2}\right.$ treated) $\mathrm{HT}-22$ and $\mathrm{HL}-1$ cells coupled with confocal laser-scanning microscopy was performed (Figure $2 b$ ). Consistent with the previous results, only apoptotic, but not necrotic or vital cells were positive for HGF. Moreover, only induction of necrosis was followed by loss of the predominant nuclear localization of HMGB1, which was typical for vital as well as apoptotic cells, indicating release of HMGB1 by the necrotic cells.

In vivo, we detected expression of cytoplasmic HGF as well as cytoplasmic/cell surface HMGB1 in the damaged myocardium after experimental myocardial ischemia/reperfusion damage, which is typically followed by apoptotic as well as necrotic cell death. ${ }^{38}$ Staining for cleaved caspase 3 and cyclophilin A confirmed apoptosis as well as necrosis in the infarcted areas. In non-infarcted healthy hearts, however, no HGF and only nuclear HMGB1 could be detected (Figure 2c). 

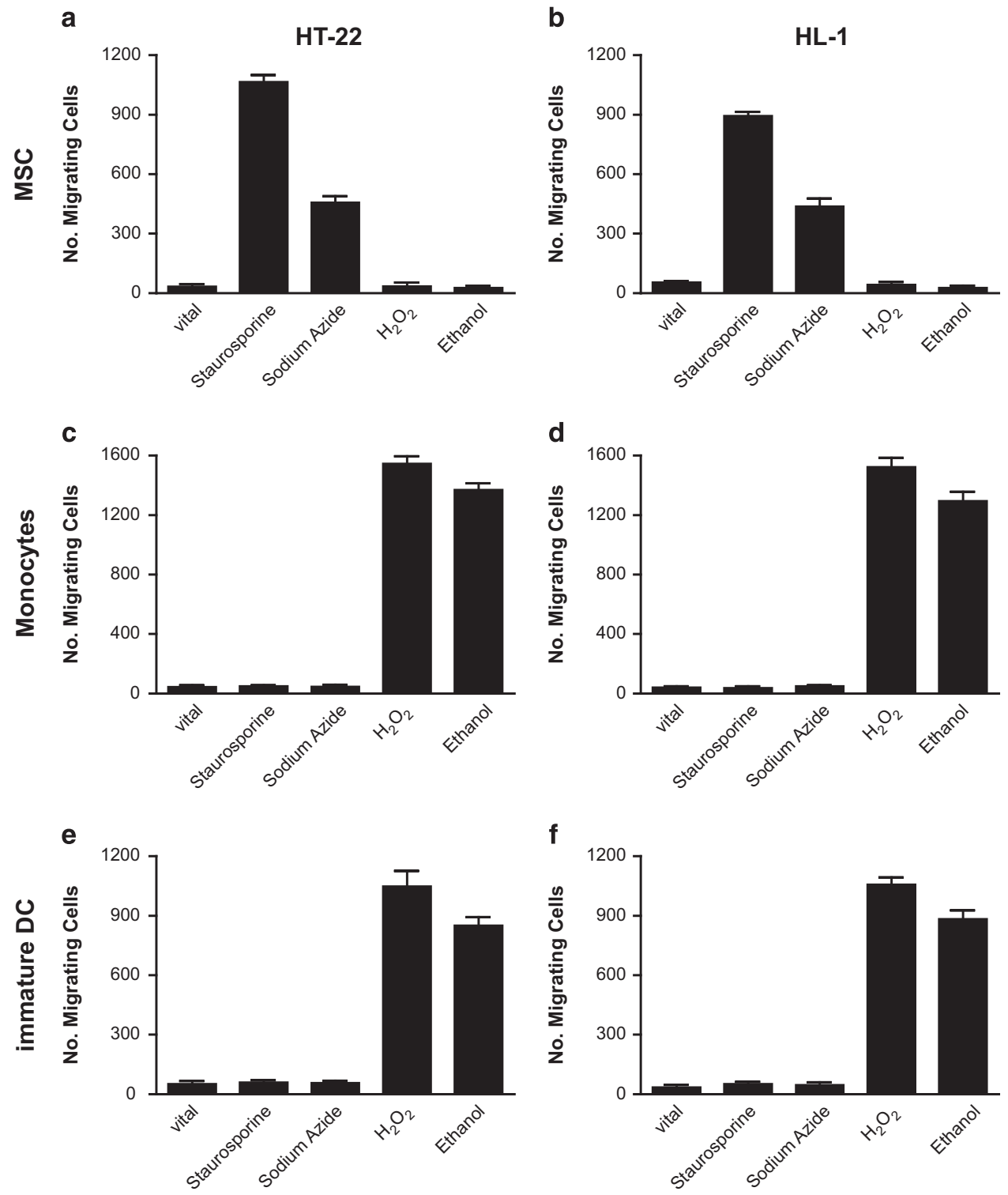

Figure 1 Migratory responses of MSC, monocytes and immature DC to apoptotic and necrotic cell death. Conditioned media derived from apoptotic (staurosporine, $300 \mathrm{nM}$, $3 \mathrm{~h}$ or sodium azide, $10 \mathrm{mM}, 3 \mathrm{~h})$, necrotic $\left(\mathrm{H}_{2} \mathrm{O}_{2}, 40 \mu \mathrm{M}, 10 \mathrm{~h}\right.$ or ethanol, $25 \%, 1 \mathrm{~h}$ ) or vital (untreated) HT-22 hippocampal neurons (a, $\mathbf{c}$ and e), and HL-1 cardiomyocytes (b, d and $\mathbf{f}$ ) were used as targets in an under-agarose chemotaxis assay for MSC (a and $\mathbf{b}$ ), monocytes (c and $\mathbf{d}$ ) or immature DC (e and $\mathbf{f}$ ). The number of migrating cells was determined after $12 \mathrm{~h}$. Data are presented as mean \pm S.E.M. for three independent experiments

Expression of receptors for HGF and HMGB1 on MSC, monocytes and immature DC. Having detected release of HGF or HMGB1 associated with apoptotic versus necrotic cell death from neuronal and cardiac cells, expression of the respective receptors, MET for HGF and RAGE, TLR-2 and TLR-4 for HMGB1, on MSC, monocytes and iDC was determined by flow cytometry (Figure 3; representative results of three). MSC expressed MET, RAGE and TLR-4, but not TLR-2, whereas all four receptors were present on monocytes and iDC, with MET being expressed at low density only.

HGF mediates attraction of MSC by apoptotic cells, HMGB1 of monocytes and immature DC by necrotic cells. To further elucidate the potential role of HGF and
HMGB1 in the cell death-dependent migratory responses of MSC, monocytes and iDC, neutralization studies were carried out. Migration of MSC towards staurosporine- or sodium azide-induced apoptotic targets (Figures $4 a$ and b) was inhibited almost completely by an anti-HGF antibody (78.6$80.6 \%$ inhibition; $P \leq 0.0011$ ), which did not affect the migratory response of monocytes (Figures $4 \mathrm{c}$ and $\mathrm{d}$ ) or iDC (Figures $4 \mathrm{e}$ and $\mathrm{f}$ ) to necrotic targets. In contrast, neutralizing HMGB1 by an anti-HMGB1 antibody significantly inhibited migration of monocytes towards $\mathrm{H}_{2} \mathrm{O}_{2}$ - or ethanol-induced necrotic HT-22 (Figure 4c; 69.4 $\pm 1.6 / 70.8 \pm 1.6 \%$ inhibition; $P<0.0001$ either condition) and $\mathrm{HL}-1$ cells (Figure $4 \mathrm{~d}$; $70.9 \pm 1.9 / 70.4 \pm 0.6 \%$ inhibition; $P \leq 0.0002$ either condition). Migration of iDC towards the necrotic targets was also suppressed by the anti-HMGB1 antibody (Figures $4 \mathrm{e}$ and f), 
a

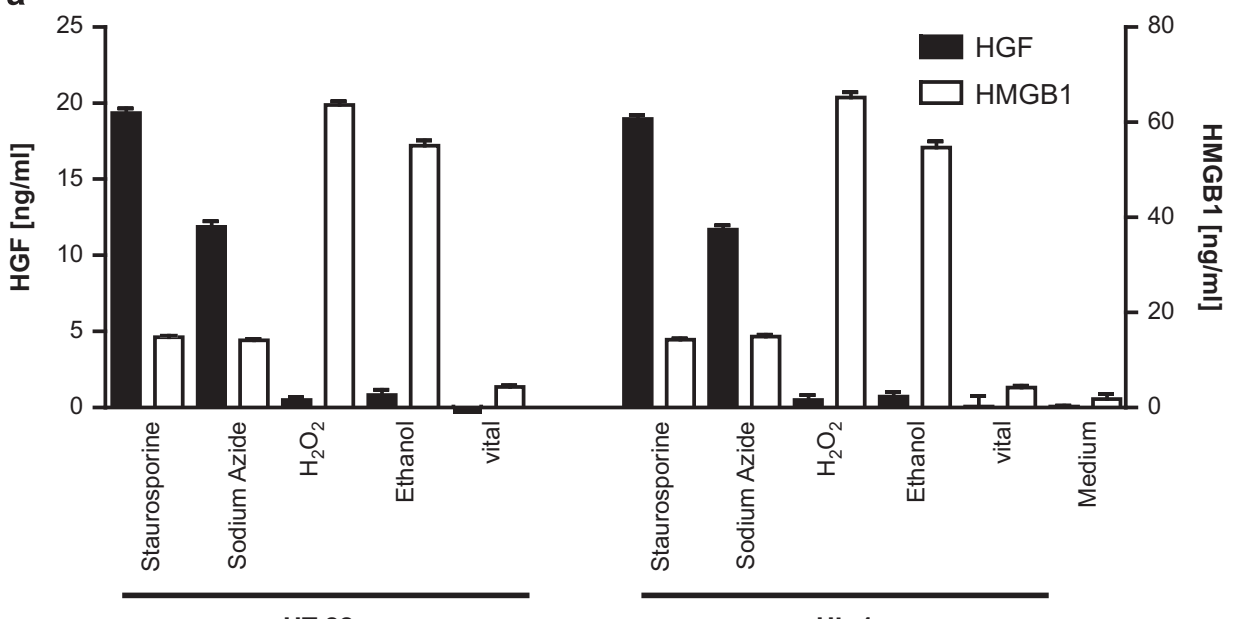

HT-22

HL-1

b

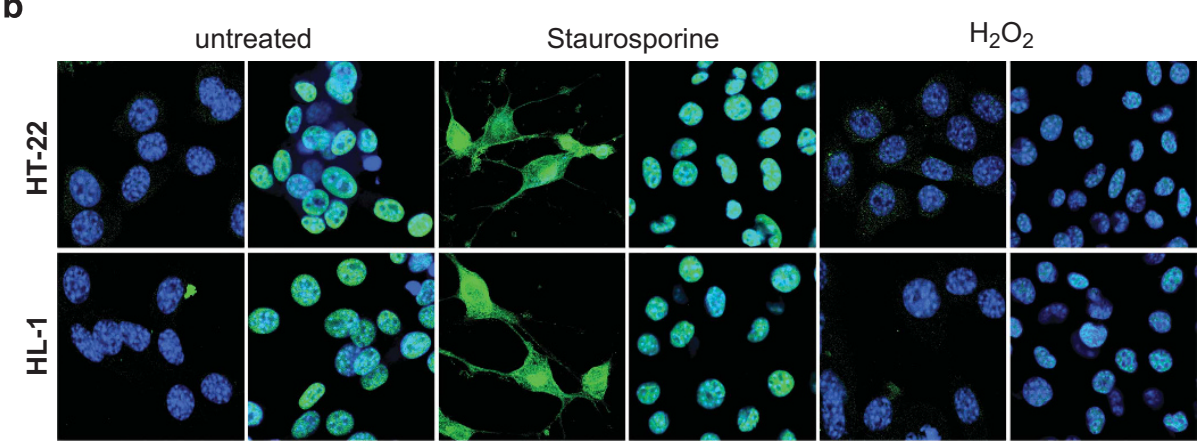

HGF

HMGB1

HGF

HMGB1

HGF

HMGB1

c
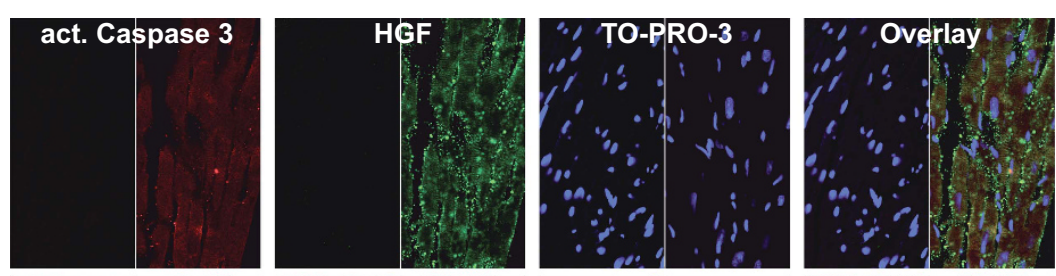

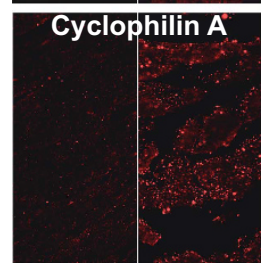

$\mathrm{HH}$

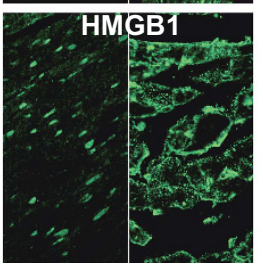

$\mathrm{HH}$

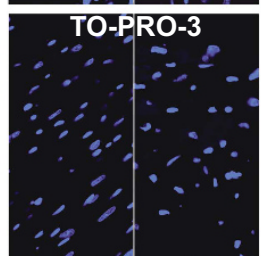

$\mathrm{HH}$

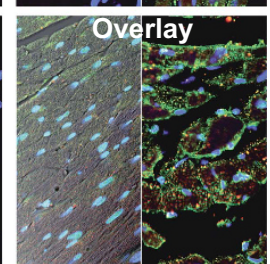

$\mathrm{HH}$

MI

Figure 2 Release of HGF and HMGB1 from apoptotic and necrotic neuronal and cardiac cells. The concentrations of HGF (black bars, left axis) and HMGB1 (open bars, right axis) in conditioned medium derived from apoptotic (staurosporine or sodium azide treatment), necrotic $\left(\mathrm{H}_{2} \mathrm{O}_{2}\right.$ or ethanol treatment) and vital (untreated) $\mathrm{HT}-22$ hippocampal neurons and $\mathrm{HL}-1$ cardiomyocytes was determined by ELISA (a). Concentrations are shown as mean \pm S.E.M. for $N \geq 2$. HGF and HMGB1 in vital (untreated), apoptotic (staurosporine treatment) and necrotic $\left(\mathrm{H}_{2} \mathrm{O}_{2}\right.$ treatment) $\mathrm{HT}-22$ and $\mathrm{HL}-1$ cells $(\mathbf{b})$ as well as in healthy hearts $(\mathrm{HH})$ or 1 day after induction of myocardial infarction (Ml) by transient ligation of the left anterior descending artery (c) were detected by immunofluorescence staining with HGF- and HMGB1-specific antibodies (green). Apoptotic cells were identified by cleaved caspase 3 staining (red), and necrotic cells by cyclophilin A staining (red). Nuclei were counterstained with TO-PRO-3 iodide (blue). Representative images of three independent experiments are shown

with inhibition ranging from 60.5 to $65.6 \%(P \leq 0.0012$ either condition). Similar results were obtained when glycyrrhizin, a specific HMGB1 inhibitor, was used (Figures 4c-f).

The chemoattractive activity of HMGB1 and HGF was confirmed by testing the migratory response of the cells towards the recombinant factors. Monocytes and iDC were attracted in a dose-dependent manner only by HMGB1 (Figure 5a), whereas HGF was chemoattractive for MSC (Figure $5 b$ ). These results were confirmed using a modified Boyden chamber (Supplementary Figure S1). MSC migration 
MSC
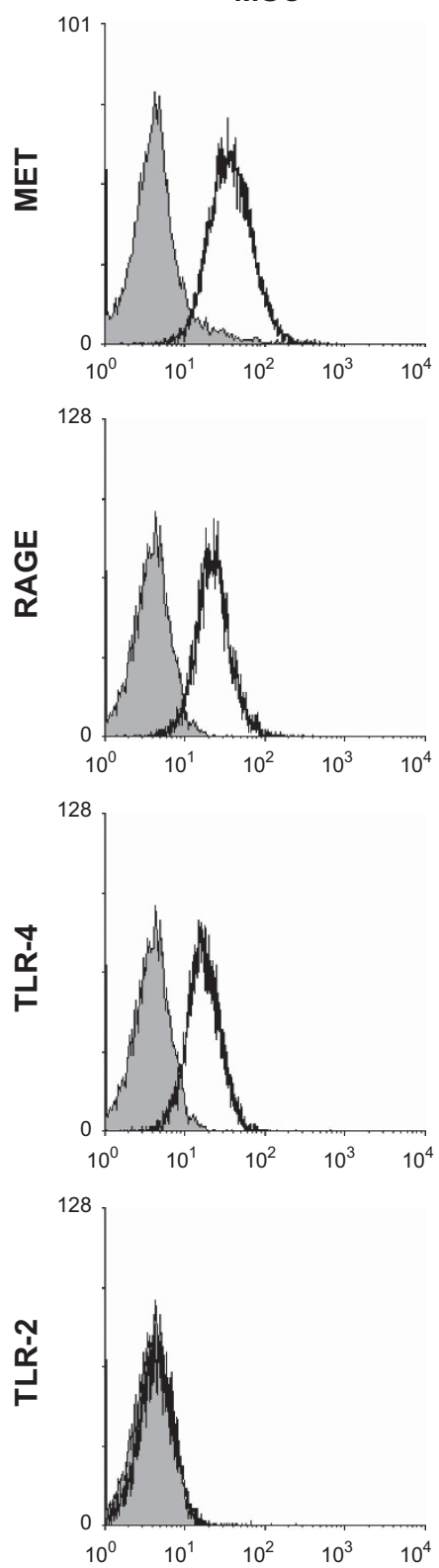

Monocytes
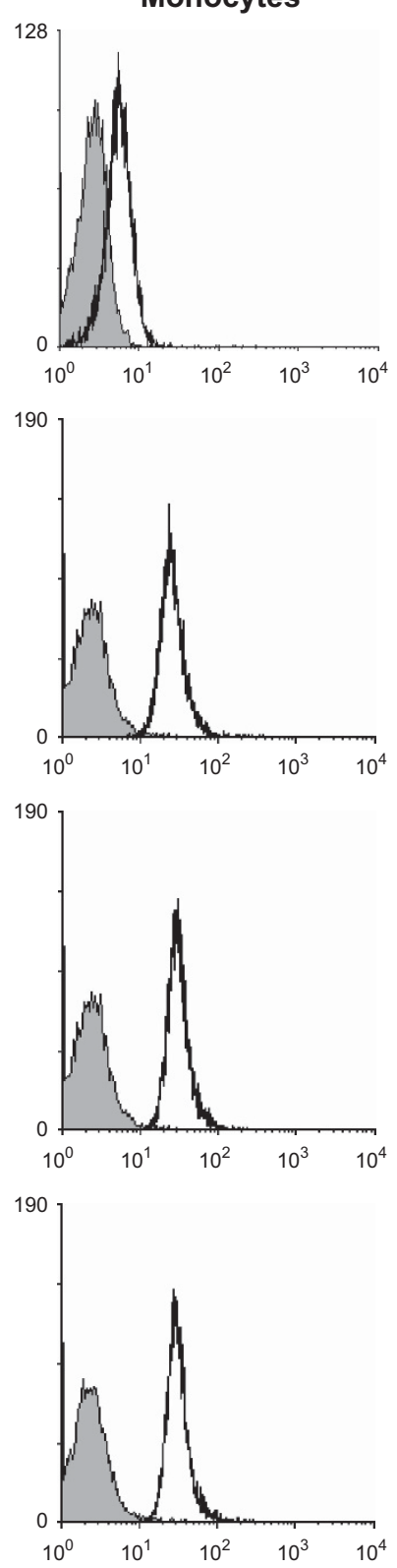
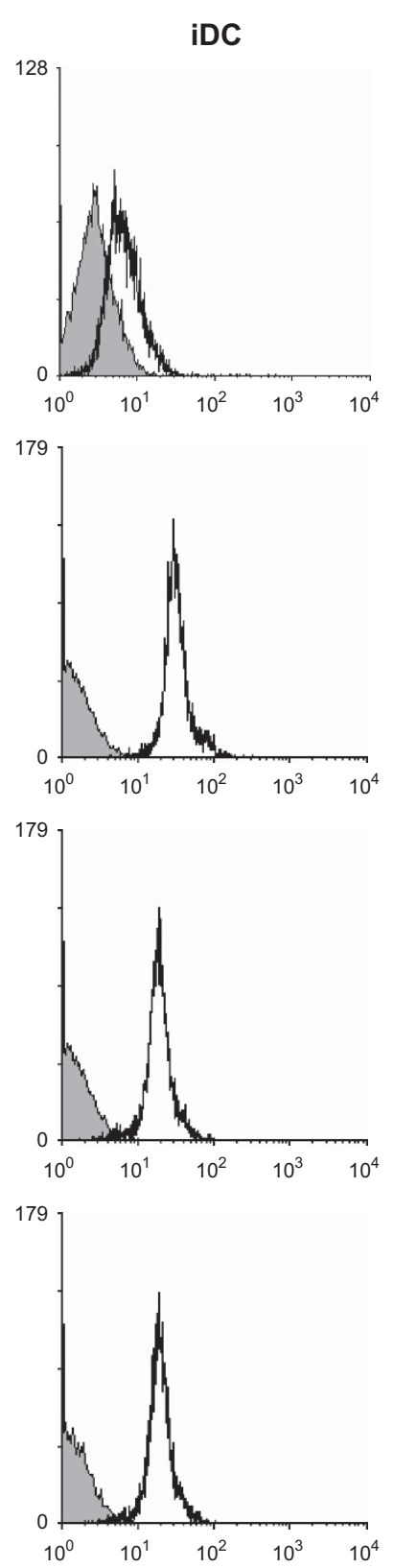

Figure 3 Expression of HGF and HMGB1 receptors on MSC, monocytes and immature DC. Expression of the HGF receptor MET and the HMGB1 receptors RAGE, TLR-2 and TLR-4 on MSC, monocytes and immature DC was determined by flow cytometry after staining with specific antibodies (open histograms). Negative isotype control stainings are shown as gray histograms

towards recombinant HGF was significantly $(P=0.0021)$ enhanced as compared with medium controls, whereas recombinant HMGB1 induced a significant $(P=0.0178)$ migratory response of monocytes.

HMGB1-driven recruitment of monocytes and IDC is mediated through RAGE. To identify the HMGB1 receptor mediating attraction of monocytes and iDC by necrotic cells, RAGE, TLR-2 or TLR-4 were blocked with neutralizing antibodies. Blocking RAGE significantly inhibited migration of monocytes (Figure 6a; 78.5 $\pm 2.2 \%$ inhibition; $P<0.0001$ ) and IDC (Figure 6b; 69.6 $\pm 5.1 \%$ inhibition; $P=0.0009$ ) towards CM of necrotic HT-22 cells. Blocking TLR-2 or
TLR-4 had no or only minimal effects. Similar results were obtained when the HL-1 target was used (data not shown). Migration of monocytes (Figure $6 \mathrm{c} ; 78.8 \pm 1.8 \%$ inhibition; $P<0.0001$ ) or iDC (Figure 6d; $70.9 \pm 3.3 \%$ inhibition; $P=0.0007$ ) initiated by recombinant HMGB1 was also substantially inhibited only in the presence of the RAGEspecific antibody. Thus, HMGB1-driven recruitment of monocytes and iDC is mediated via the RAGE receptor.

HMGB1 suppresses HGF-mediated chemoattraction of MSC via TLR-4. Next, we assessed whether HGF influences the chemoattractive activity of HMGB1 and vice versa. Migration of MSC towards recombinant HGF was inhibited 
a
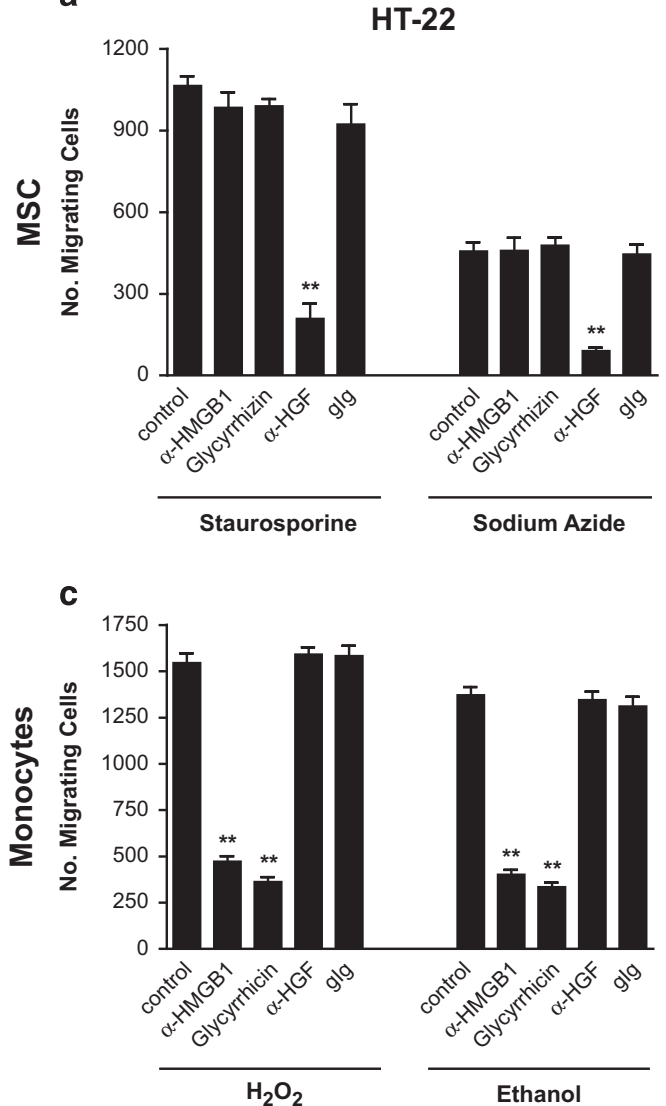

e

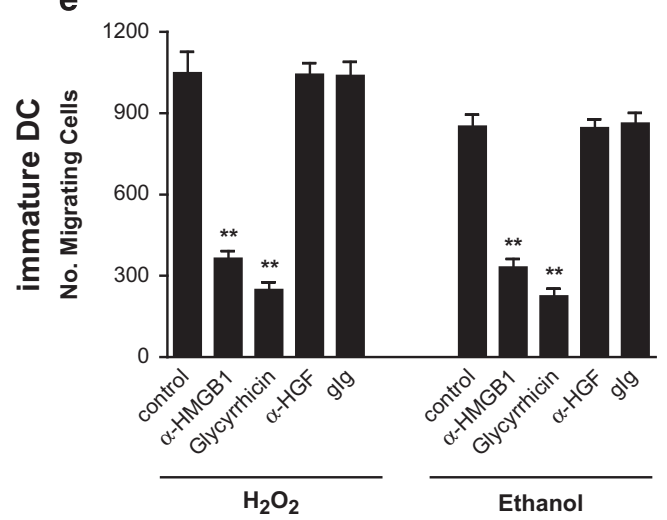

b

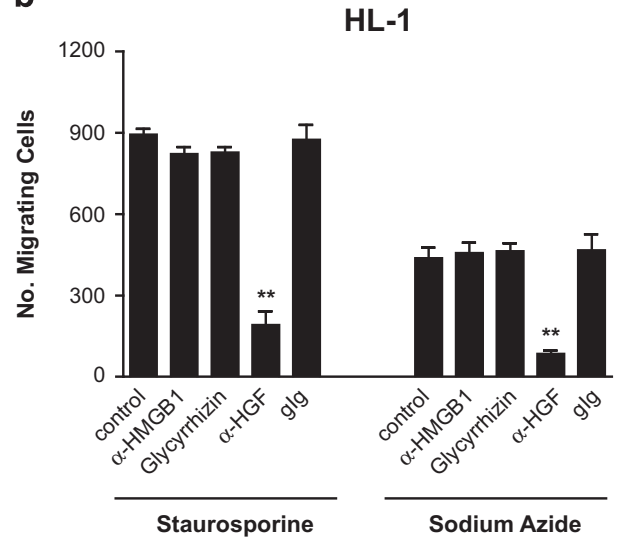

d

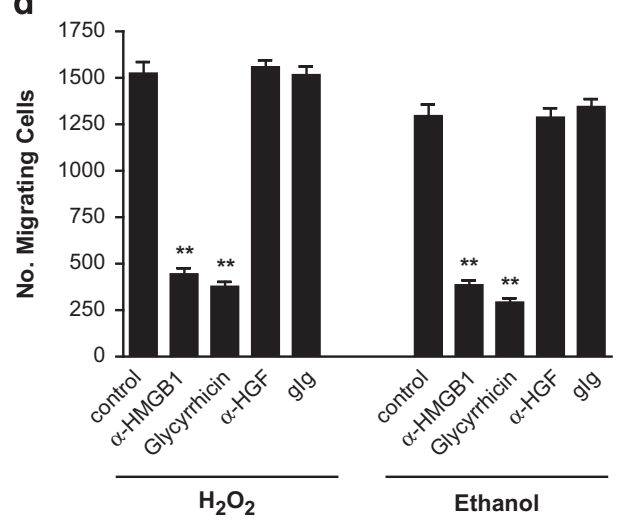

f

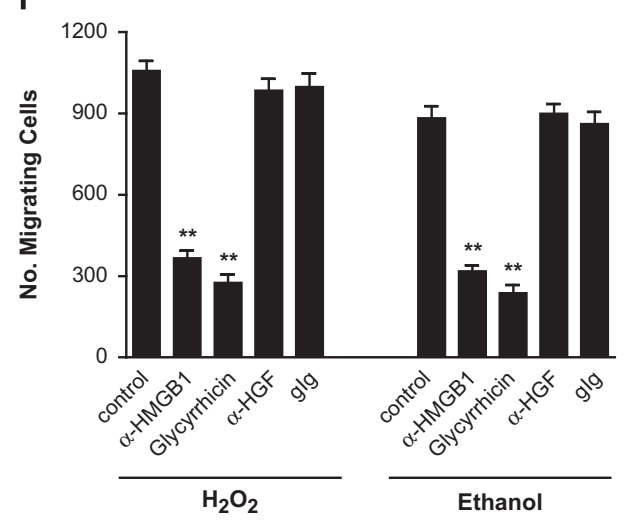

Figure 4 Role of HGF and HMGB1 in apoptosis- and necrosis-induced migration of MSC, monocytes and immature DC. Migration of MSC (a and $\mathbf{b})$, monocytes (c and $\mathbf{d})$ and immature DC (e and f) towards conditioned medium derived from apoptotic (staurosporine or sodium azide treatment; $\mathbf{a}$ and $\mathbf{b})$ or necrotic $\left(\mathrm{H}_{2} \mathrm{O}_{2}\right.$ or ethanol treatment; $\left.\mathbf{c}-\mathbf{f}\right)$ $\mathrm{HT}$-22 hippocampal neurons (a, $\mathbf{c}$ and $\mathbf{e}$ ) or $\mathrm{HL}-1$ cardiomyocytes $(\mathbf{b}, \mathbf{d}$ and $\mathbf{f})$ was determined in an under-agarose chemotaxis assay in the presence or absence of neutralizing antibodies to HGF $(2 \mu \mathrm{g} / \mathrm{ml})$ or HMGB1 $(2 \mu \mathrm{g} / \mathrm{ml})$ or of the HMGB1-inhibitor glycyrrhizin $(10 \mu \mathrm{g} / \mathrm{ml})$. Goat lg $(2 \mu \mathrm{g} / \mathrm{ml})$ served as negative control. Data are presented as mean \pm S.E.M. for three independent experiments. Statistical significance $\left({ }^{* *} P \leq 0.01\right)$ is indicated

dose-dependently by HMGB1 (Figure 7a), irrespective of whether HMGB1 was mixed with the target or MSC were pre-incubated for $12 \mathrm{~h}$ with HMGB1 before they were used in the migration assay (Figure 7b). Delayed addition of HMGB1 to the target $3 \mathrm{~h}$ after migration of MSC was initiated, however, resulted in a reduced inhibition of migration (Figure $7 \mathrm{~b}$ ). Consistent with this observation, $\mathrm{CM}$ of necrotic $\mathrm{HT}-22$ and $\mathrm{HL}-1$ cells inhibited migration of MSC towards CM of apoptotic cells (data not shown).
To identify the receptor that mediates inhibition of HGFinduced migration of MSC by HMGB1, MSC were preincubated with blocking antibodies against RAGE, TLR-2 or TLR-4 and then tested for their migration towards a mixture of HGF and HMGB1, which does not permit migration due to the inhibitory effect of HMGB1. Only blocking TLR-4 on MSC could substantially reverse the inhibitory effect of HMGB1 on MSC migration towards HGF (Figure 7c), indicating a TLR-4dependent phenomenon. In contrast, HGF had no effect on 
a

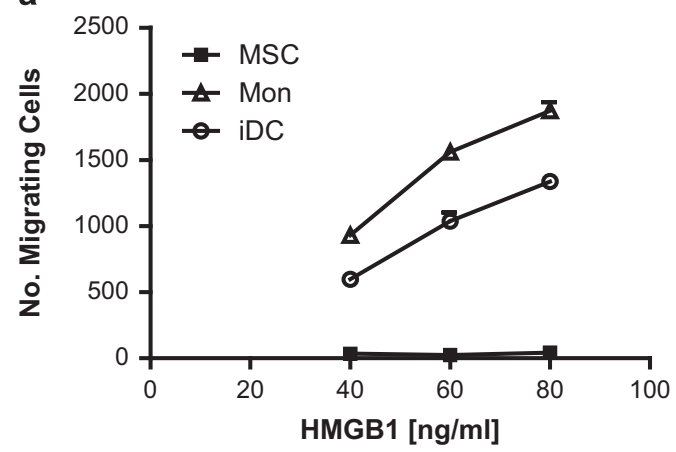

b

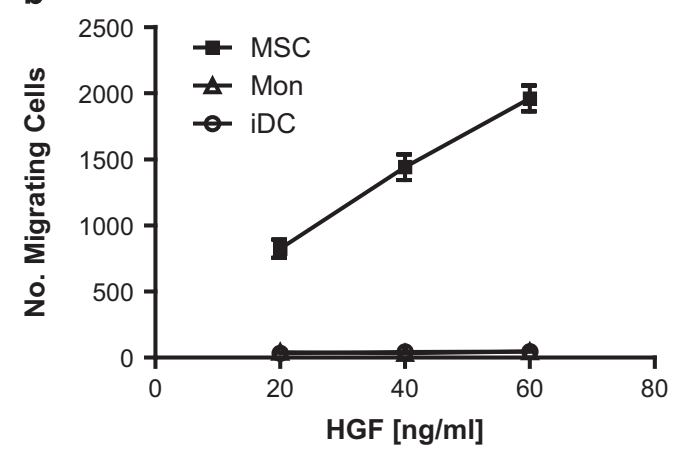

Figure 5 Migratory response of MSC, monocytes and immature DC to recombinant $\mathrm{HGF}$ and $\mathrm{HMGB1}$. The migration of MSC, monocytes and immature DC towards graded doses of HMGB1 (a) or HGF (b) was determined in an under-agarose chemotaxis assay. Data are presented as mean \pm S.E.M. for three independent experiments recruitment of monocytes or iDC induced by HMGB1 (Figure 7d).

Because these observations were very suggestive, we finally investigated in vivo the role of HMGB1 in recruitment of Mac-3-positive macrophages and cells expressing CD271, which may be considered as a marker for MSC. ${ }^{39}$ In an experimental myocardial infarction model, intravenous injection of a neutralizing anti-HMGB1 antibody $10 \mathrm{~min}$ prior to transient ligation of the left anterior descending artery substantially reduced Mac-3-positive macrophage infiltrates in the damaged myocardium as compared with control animals receiving injections of an isotype control antibody (Figure 8, upper panel; representative results of three animals each). However, infiltrated CD271-positive cells indicative for potentially regenerative MSC in the infarcted areas were notably increased when systemically suppressing HMGB1 bioactivity with the neutralizing antibody as compared with isotype control antibody (Figure 8, lower panel; representative results of three animals each), confirming a critical role of HMGB1 in promoting monocyte/macrophage recruitment and possibly interfering with MSC migration into damaged tissues in vivo.

\section{Discussion}

Distinct cellular programs are activated during tissue damage to ensure either direct tissue repair and regeneration or initiation of inflammatory processes, which may pave the way for the development of immune responses required to clear debris as well as potential damage-inducing agents, prior to
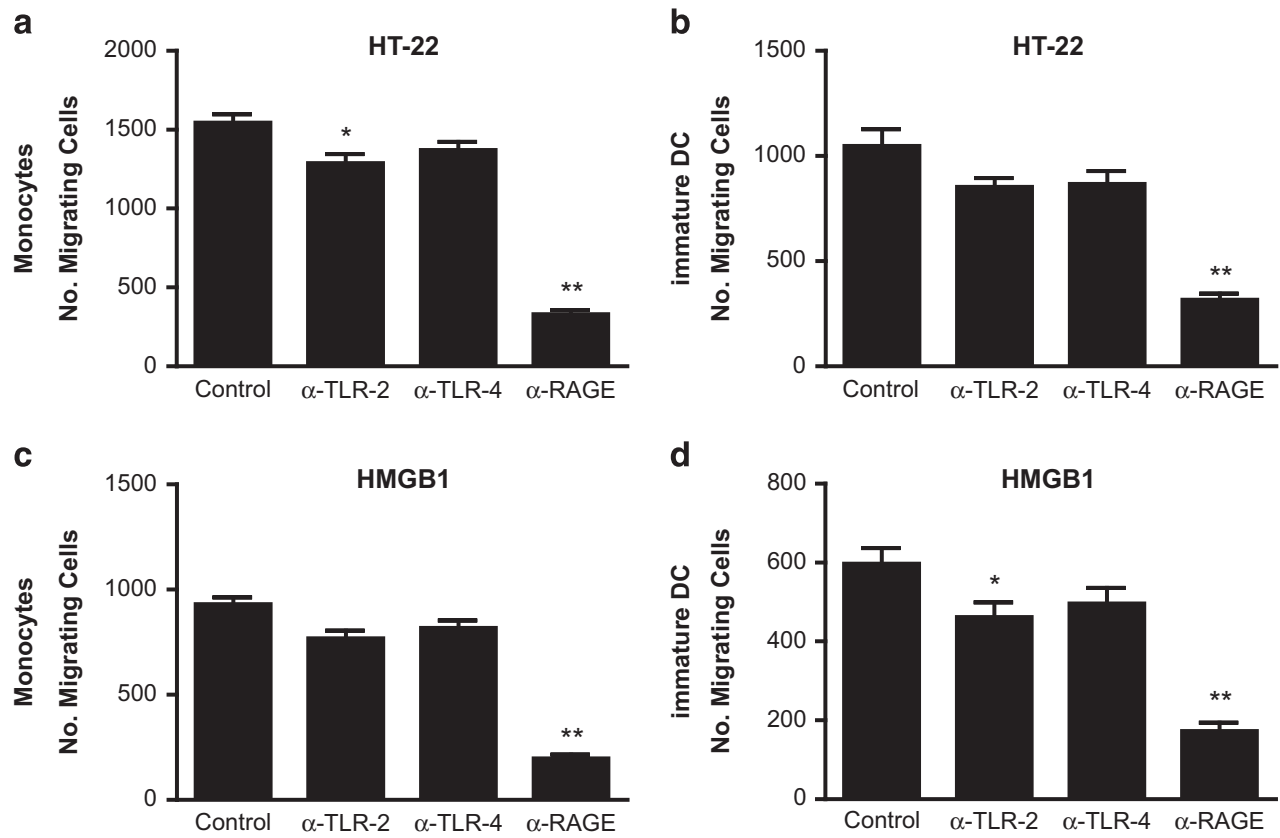

Figure 6 Contribution of individual HMGB1 receptors to the HMGB1-induced migration of monocytes and immature DC. Migration of monocytes (a and c) and immature DC ( $\mathbf{b}$ and $\mathbf{d}$ ) towards conditioned medium derived from necrotic HT-22 hippocampal neurons (a and $\mathbf{b}$ ) or $40 \mathrm{ng} / \mathrm{ml}$ recombinant HMGB1 (c and $\mathbf{d}$ ) was determined in an underagarose migration assay in the presence or absence of neutralizing antibodies to RAGE, TLR-2 and TLR-4. Data are presented as mean \pm S.E.M. for three independent experiments. Statistical significance $\left({ }^{*} P \leq 0.05 ;{ }^{* *} P \leq 0.01\right)$ is indicated 

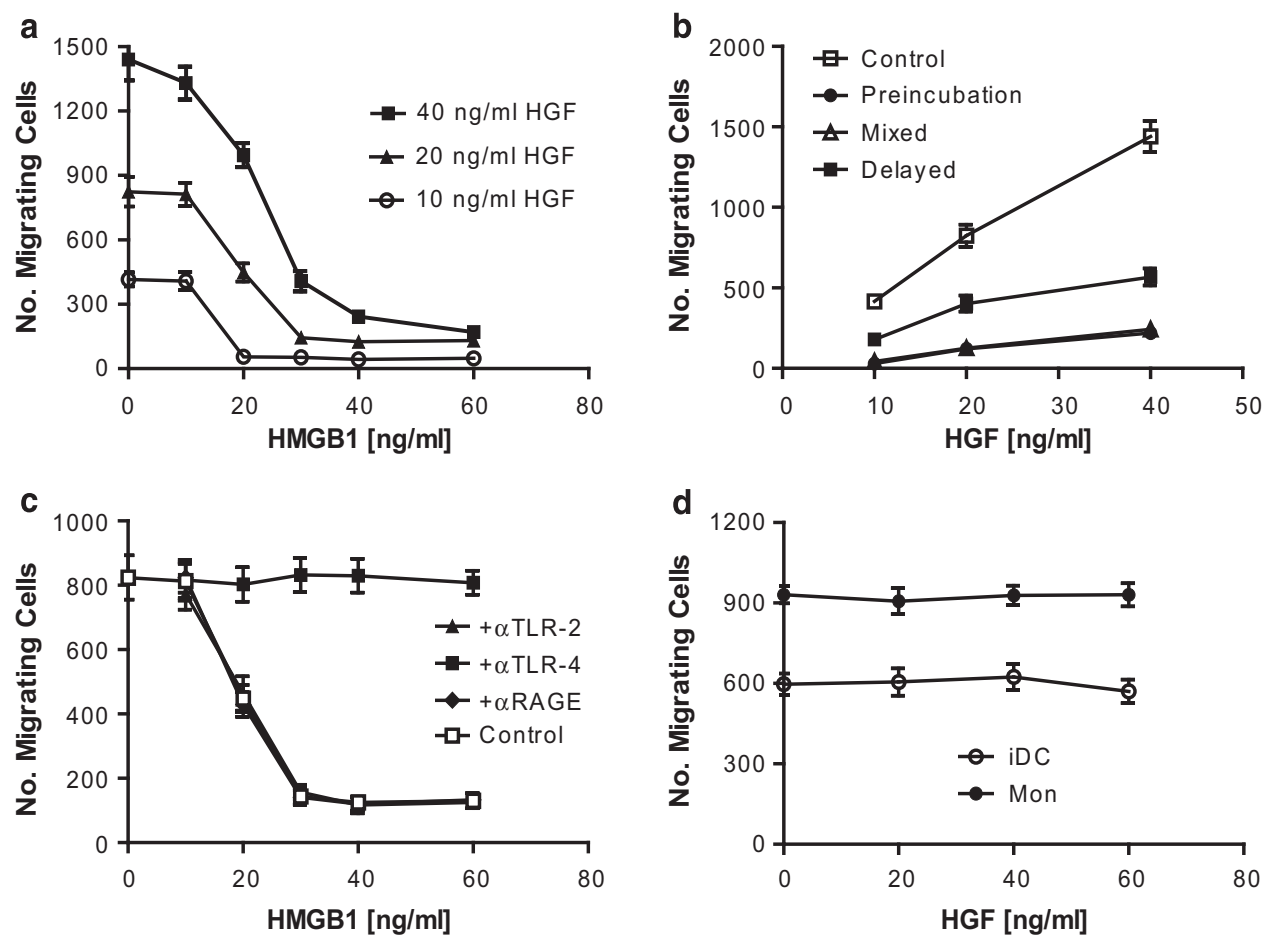

Figure 7 Effect of HMGB1 on HGF-induced migration of MSC. Migration of MSC towards recombinant HGF was studied in the presence of graded doses of HMGB1 (a). HMGB1 ( $40 \mathrm{ng} / \mathrm{ml}$ ) was either mixed with the target, MSC were pre-incubated with HMGB1 or it was added $3 \mathrm{~h}$ after migration of MSC towards HGF had been initiated (b) In neutralization studies, MSC were pre-incubated with antibodies to RAGE, TLR-2 and TLR-4 and then migration towards $20 \mathrm{ng} / \mathrm{ml} \mathrm{HGF}$ was initiated in the presence of graded doses of HMGB1 (c). Migration of monocytes and immature DC towards HMGB1 $(40 \mathrm{ng} / \mathrm{ml})$ was studied in the presence of graded doses of HGF (d). The number of migrating cells was determined after $12 \mathrm{~h}$ in an under-agarose migration assay. Data are presented as mean \pm S.E.M. for three independent experiments
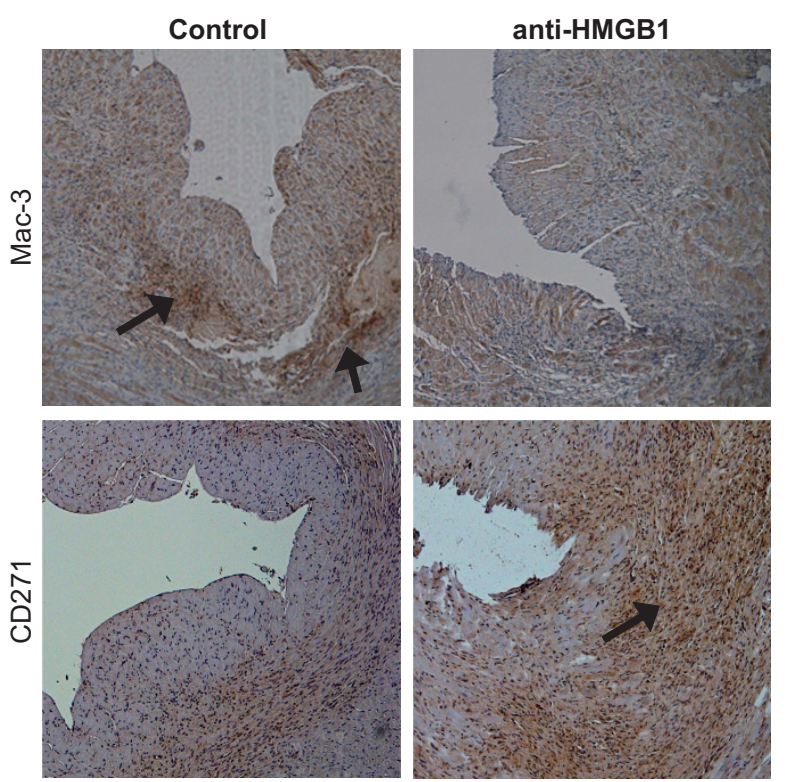

Figure 8 Infiltrated Mac-3- and CD271-positive cells in infarcted hearts after antiHMGB1 treatment. Neutralizing anti-HMGB1 antibody $(2 \mu \mathrm{g} / \mathrm{g}$ body weight) or control antibody was injected intravenously into C57BL/6J mice 10 min prior to induction of myocardial infarction by transient ligation of the left anterior descending artery. After $24 \mathrm{~h}$, mice were killed, and paraffin-embedded sections were stained with Mac-3specific, CD271-specific or IgG control antibodies. Mac-3-positive (upper panel) and CD271-positive cell infiltrates (lower panel) are indicated by arrows. Isotype controls revealed no staining (data not shown). Representative images of three independent experiments are shown tissue remodeling or repair. ${ }^{1}$ The type of cell death during tissue injury appears to have a key role in a differential initiation of these processes. We have identified HGF and HMGB1, which are released upon apoptotic and necrotic cell death of cardiomyocytic as well as neuronal cells, respectively, to be responsible for the recruitment of distinct cell types with either regenerative or immunological properties. Apoptotic cells secreted HGF attracting MSC, whereas necrotic cells released HMGB1 responsible for recruitment of monocytes and iDC. Moreover, HMGB1 released from necrotic cells at the same time inhibited the HGF-driven migratory response of MSC.

Release of HMGB1 as a result of necrotic cell death during tissue damage is well established $\mathrm{d}^{25,26,40}$ and has been confirmed here for necrotic cardiomyocytes in vitro as well as in vivo after myocardial infarction. However, HMGB1 release from apoptotic cells has also been reported, including from staurosporine-treated Jurkat, U937 and HeLa cells. ${ }^{27}$ Although apoptotic cardiomyocytic and neuronal cells also released in vitro moderate doses of HMGB1 in this study, these failed to attract monocytes or iDC, whereas HMGB1 from necrotic cells or recombinant HMGB1 did. This may be due to a dose effect. Moreover, during apoptotic cell death, critical cysteine residues of HMGB1 can become oxidized due to caspase-dependent production of reactive oxygen species, preventing HMGB1 binding to RAGE as well as the TLR receptors. ${ }^{28,29}$ Thus, HMGB1 released after staurosporine or sodium azide-induced apoptotic cell death may be biologically 
inactive. Whether other means of inducing apoptosis, for example, immunogenic apoptosis, will result in a higher release of biologically active HMGB1 needs to be determined.

After experimental myocardial ischemia/reperfusion damage, which is typically followed by apoptotic as well as necrotic cell death, ${ }^{38}$ expression of cytoplasmic HGF as well as cytoplasmic/cell surface HMGB1 was observed. Further, macrophage infiltration of the infarcted area was substantially suppressed by injection of a neutralizing anti-HMGB1 antibody prior to myocardial infarction, indicating an HMGB1dependent phenomenon like it has been observed in vitro as well. Interestingly, infiltrated CD271-positive cells indicative for $\mathrm{MSC}^{39}$ in the infarcted areas were notably increased in antiHMGB1-treated animals, which supports our in vitro observation of HMGB1 interfering with apoptosis-induced MSC recruitment. Thereby, therapeutically suppressing HMGB1 bioactivity with a specific inhibitor might increase recruitment of endogenous MSC into infarcted hearts but it might also substantially improve efficacy of transplantation of regenerative MSC. Further in vivo studies are needed that may help identify HMGB1 as a target for MSC-based therapy after myocardial damage.

Irrespective of monocytes and iDC expressing the HMGB1 receptors RAGE, TLR-2 and TLR-4 at apparent high density, attraction by either necrotic cell-derived or recombinant HMGB1 was only mediated via RAGE. This implies that HMGB1 released by necrotic cells may be in its all-thiol form, which is required for RAGE binding. ${ }^{28,29}$ In addition, RAGE dependency of its migratory effect suggests that HMGB1 by itself acts as a chemoattractant and does not require the formation of complexes with CXCL12, because these have been reported to signal via $\mathrm{C}-\mathrm{X}-\mathrm{C}$ chemokine receptor type 4 (CXCR4). ${ }^{32,41}$ This conclusion is further supported by the under-agarose migration assay employed here: when recombinant HMGB1 was used as a target, only a stable gradient of HMGB1 could form, along which the cells could migrate, whereas the concentration of CXCL12, if produced by the monocytes and iDC, would have been highest at the site of these cells. HMGB1/RAGE-mediated attraction of monocytes/ macrophages and iDC has also been described by others. ${ }^{42,43}$ However, additional autocrine/paracrine effects cannot be ruled out. Dumitriu et al. ${ }^{44}$ have shown that HMGB1 released by $\mathrm{DC}$ after activation is necessary for their migration towards the chemokines CXCL12 and C-C motif ligand 19 (CCL19) due to upregulation of CXCR4 and $\mathrm{C}-\mathrm{C}$ chemokine receptor type 7 (CCR7), respectively, and thus may contribute to lymph node homing. In our study, neither anti-HMGB1 nor anti-RAGE nor glycyrrhizin inhibited migration of monocytes or iDC completely. Thus, other factors appear to contribute to the necrotic cell death-driven chemoattraction as well, which so far have not been identified.

Necrotic cell death and HMGB1 were only chemoattractive for monocytes and iDC, but not for MSC, although MSC expressed the HMGB1 receptors RAGE and TLR-4. This observation appears to be in conflict with previous studies. $^{36,45,46}$ Interestingly, the HMGB1-driven migratory responses of MSC in these studies have either been independent of RAGE ${ }^{36,46}$ or the type of receptor has not been assessed, ${ }^{45}$ which could imply a possible role of HMGB1/ CXCL12 complexes. On the other hand, RAGE-mediated chemoattractive activity of HMGB1 has been documented for other stem and progenitor cells, including endothelial progenitor cells, ${ }^{37}$ as well as for progeny of MSC-like smooth muscle cells ${ }^{47}$ and fibroblasts. ${ }^{48}$ Whether such differences in the migratory responsiveness of MSC to HMGB1 are possibly due to subpopulations, the presence of certain co-factors or differences in culture conditions needs to be determined.

MSC, however, did migrate towards apoptotic cell death and attraction was mediated by HGF. We could show in a previous study that HGF is transcribed and released after induction of apoptosis in cardiomyocytes and neurons, whereas it is not detected in necrotic or vital cells. ${ }^{9}$ Indeed, HGF is a potent chemoattractant for stem and progenitor cells expressing HGF receptor MET, such as $\mathrm{MSC}^{4}$ endothelial progenitor cells, ${ }^{15}$ cardiac stem cells, ${ }^{13}$ neural stem cells ${ }^{14}$ and cord bloodderived unrestricted somatic stem cells. ${ }^{8}$ In contrast, apoptosis- or recombinant HGF-induced attraction of monocytes or iDC was not detected despite low level expression of the HGF receptor MET on monocytes and iDC. Although HGF has been shown to enhance monocyte and iDC migration, it appears to increase motility rather than to act as a chemoattractant for these cells, ${ }^{49,50}$ further confirming that the under-agarose migration assay used here is suitable to detect site-directed migration and not only changes in overall cellular motility.

Remarkably, when both signals, HGF and HMGB1, were present together, HMGB1 was dominant. It not only induced RAGE-dependent recruitment of monocytes and iDC, probably directing cellular responses towards inflammation and an immune response, but it also inhibited HGF-driven migration of MSC, thereby possibly preventing their immunosuppressive influence at sites of tissue damage, when both, apoptotic and necrotic cell deaths coincide. Inhibition of the migratory responsiveness of MSC by HMGB1 was dependent on TLR-4, thus, engagement of different receptors is responsible for either inducing migration of monocytes and iDC or suppressing migration of MSC. The underlying molecular mechanism responsible for this HMGB1/TLR-4-mediated inhibition of chemoattraction of MSC by HGF is currently under investigation. In two previous studies, which have reported HMGB1induced, TLR-4-dependent inhibition of the migratory responses of enterocytes ${ }^{51}$ and pulmonary artery endothelial cells, ${ }^{52}$ an increase in cell force adhesion and activation of interferon response factor 3 but not nuclear factor kappa B have been shown to contribute.

The potential of HMGB1 to overcome immunosuppressive mechanisms associated with apoptosis is further supported by the observation that HMGB1 release is a decisive feature for immunogenicity of apoptosis, ${ }^{53}$ in part by inhibiting efferocytosis and thereby preventing the rapid removal of apoptotic bodies from the tissue. ${ }^{54}$ Moreover, engagement of TLR-4 on MSC by lipopolysaccharide has been shown to result in the generation of pro-inflammatory $\mathrm{MSC}^{55}$ and to suppress their immunosuppressive activity, ${ }^{56}$ although this is still a matter of debate. ${ }^{57}$ Whether HMGB1 induces a similar phenotype in MSC is currently being determined. However, these effects of a microbial TLR ligand suggest that in the course of infections it is ensured that apoptotic cell death does not prevent immune responses.

Thus, depending on the type of cell death during tissue injury, two different factors are released, which recruit distinct 
cell populations. Apoptosis via secretion of HGF appears to pave the way for tissue regeneration concomitant with maintaining immunological tolerance, because HGF and the MSC recruited by HGF have regenerative as well as immunosuppressive activities. In contrast, monocytes, iDC and their chemoattractant HMGB1, which is released during necrotic cell death, are immunostimulatory and may initiate inflammatory processes or adaptive immune responses rather than tissue regeneration, which appears to be actively suppressed by HMGB1/TLR-4-mediated inhibition of MSC recruitment to apoptotic cells.

\section{Materials and Methods}

MSC, monocytes and iDC. Human BM was obtained from volunteer donors after informed consent with approval of the local ethical committee. MSC were isolated from $\mathrm{BM}$ as previously described. ${ }^{9}$ Briefly, BM mononuclear cells were allowed to adhere to $75-\mathrm{cm}^{2}$ cell culture flasks (Greiner Bio-One, Nürtingen, Germany) in Dulbecco's modified Eagle's medium (DMEM; Lonza, Verviers, Belgium) supplemented with $30 \%$ fetal calf serum (FCS; GIBCO/Invitrogen, Karlsruhe, Germany), $100 \mathrm{U} / \mathrm{ml}$ penicillin, $100 \mu \mathrm{g} / \mathrm{ml}$ streptomycin and $2 \mathrm{mM}$ L-glutamine (all from Lonza). After $48 \mathrm{~h}$ of cell culture at $37^{\circ} \mathrm{C}$ and $5 \% \mathrm{CO}_{2}$, nonadherent cells were removed. When the adherent layer reached $80 \%$ confluence, cells were detached with $0.25 \%$ trypsin in phosphate-buffered saline (PBS; Lonza) and re-plated at $1: 3$. Only cells from passages 3-9 of 6 different MSC preparations were used in experiments. All of them showed an immunophenotype typical for MSC: ${ }^{16}$ positive for CD13, CD29, CD44, CD71, CD73, CD90, CD105 and HLA-class I, and negative for the lineage markers CD3, CD14, CD19, CD235a, CD31 and CD326 as well as CD45 and HLA-DR (Supplementary Figure S2A). Furthermore, MSC differentiated along osteogenic and adipogenic pathways as described (Supplementary Figure S2B and C). ${ }^{16}$

$\mathrm{CD}_{14}{ }^{+}$monocytes were isolated from peripheral blood mononuclear cells by positive selection using LS separation columns on a VarioMACS (Miltenyi Biotec, Bergisch Gladbach, Germany) according to the instructions of the manufacturer. $\mathrm{CD} 14^{+}$purity of cells was $\geq 90 \%$. Generation of $\mathrm{iDC}$ from $\mathrm{CD} 14^{+}$monocytes followed a protocol described previously. ${ }^{58}$ Briefly, monocytes were cultured in 24-well plates (Greiner Bio-One) at a density of $1 \times 10^{6}$ cells $/ \mathrm{ml}$ in $2 \mathrm{ml}$ per well of serum-free CellGroDC medium (CellGenix, Freiburg, Germany) supplemented with $1000 \mathrm{U} / \mathrm{ml}$ granulocyte macrophage-colony stimulating factor (CellGenix) and $1000 \mathrm{U} / \mathrm{ml}$ interleukin-4 (CellGenix). After 3 days of culture, half of the medium was exchanged with fresh medium containing cytokines, and after 6 days iDC were harvested. They lacked CD83 expression and had downregulated the monocyte marker CD14 (data not shown).

Induction of apoptosis and necrosis in neuronal and cardiac cells. HT-22 murine hippocampal neurons were cultured in DMEM medium supplemented with $10 \%$ FCS, antibiotics and L-glutamine. HL-1 murine cardiac myocytes were cultured in Claycomb medium (Sigma-Aldrich, Taufkirchen, Germany) supplemented with $10 \%$ FCS, antibiotics, L-glutamine and $0.1 \mathrm{mM}$ norepinephrine (Sigma-Aldrich). ${ }^{9}$ All cell cultures were incubated at $37^{\circ} \mathrm{C}$ and $5 \%$ $\mathrm{CO}_{2}$ in a humidified atmosphere.

Induction of apoptosis was carried out by treatment of $5 \times 10^{6}$ cells with $300 \mathrm{nM}$ staurosporine (Calbiochem, Bad Soden, Germany) or $10 \mathrm{mM}$ sodium azide (SigmaAldrich) for $3 \mathrm{~h}$ in a volume of $15 \mathrm{ml}$ of culture medium in T75 culture flasks. ${ }^{8,9}$ Necrotic cell death was initiated by incubation with $40 \mu \mathrm{M} \mathrm{H}_{2} \mathrm{O}_{2}$ (Sigma-Aldrich) for $10 \mathrm{~h}$ or $25 \%$ ethanol (Sigma-Aldrich) for $1 \mathrm{~h}^{8,9}$ After induction of apoptosis or necrosis, culture medium $(15 \mathrm{ml})$ was exchanged, and cells were incubated for an additional $12 \mathrm{~h}$ before $\mathrm{CM}$ was harvested. Apoptotic cells were Annexin $\mathrm{V}^{+} /$propidium iodine $^{-}$and revealed positive terminal deoxynucleotidyl transferase dUTP nick end labeling, whereas necrotic cells were Annexin $\mathrm{V}^{-}$/propidium iodine ${ }^{+}$and negative for DNA fragmentation as described before. ${ }^{9}$ Moreover, only apoptotic (staurosporine treated and sodium azide treated), but not vital (untreated) or necrotic $\left(\mathrm{H}_{2} \mathrm{O}_{2}\right.$ treated and ethanol treated) $\mathrm{HT}-22$ and $\mathrm{HL}-1$ cells were positive for intracellular cleaved caspase 3 , as determined by immunofluorescence staining (see below) with a polyclonal antibody against active (cleaved) caspase $3(5 \mu \mathrm{g} / \mathrm{ml}$; rabbit lgG; Abcam, Cambridge, UK) and confocal laser-scanning microscopy (Supplementary Figure $\mathrm{S} 3 \mathrm{~A}$ ). In addition, Western blot analyses identified cleaved caspase 3 only in apoptotic (staurosporine), but not in necrotic $\left(\mathrm{H}_{2} \mathrm{O}_{2}\right)$ or vital $\mathrm{HT}-22$ cells and showed the presence of cleaved poly (ADP-ribose) polymerase-1 (PARP-1) in the apoptotic, but only at very low levels in the necrotic cells. PARP-1 was absent in the vital cells (Supplementary Figure 3B).

Under-agarose chemotaxis assay. An under-agarose chemotaxis assay was performed as described before ${ }^{9}$ to investigate migration of MSC, monocytes and iDC towards the various targets. Briefly, $0.8 \%$ agarose (Eurogentec, Cologne, Germany) in PBS was boiled, mixed with $0.5 \%$ bovine serum albumin (BSA; Roth, Karlsruhe, Germany) in DMEM medium (for MSC) or CellGroDC medium (for monocytes and iDC) after cooling, and poured into the wells of a six-well plate (Costar/Corning, Wiesbaden, Germany). After the agarose had solidified, three $2 \mathrm{~mm}$ wide and $10 \mathrm{~mm}$ long slots $5 \mathrm{~mm}$ apart from each other were cut in the agarose of each well. MSC $\left(8 \times 10^{4}\right)$ or monocytes $\left(1 \times 10^{5}\right)$ or iDC were added to the central slots of each well, $70 \mu \mathrm{l}$ of chemoattractant were placed in the left slots and migration medium (negative control) in the right slots. The number of cells that had migrated to the target slot subtracted by the number of cells that had migrated to the negative control slot was defined as the number of specifically migrating cells and was documented after a $12 \mathrm{~h}$ migration period at $37^{\circ} \mathrm{C}$ in a humidified atmosphere and $5 \% \mathrm{CO}_{2}$.

CM $(100 \%)$ derived from vital, apoptotic and necrotic HT-22 or HL-1 cells, recombinant HGF (10-60 ng/ml; R\&D Systems, Wiesbaden, Germany) and recombinant HMGB1 (10-80 ng/ml; R\&D Systems) served as chemoattractants. Carry-over of apoptosis inducers with the conditioned media appears to be negligibly small with this approach. When graded doses of staurosporine or sodium azide were placed in the target slot of an under-agarose chemotaxis assay (see below), (a) no migration of MSC, monocytes or IDC was induced, and (b) after the $12 \mathrm{~h}$ standard migration period almost all cells in the center slot were dead (data not shown), most likely due to diffusion of the apoptosis inducers into the center slot. Such effects have not been observed in the experiments performed for this study, all of which revealed reliable and significant migratory responses of vital cells.

Neutralization studies were carried out by adding anti-mHGF polyclonal antibody ( $2 \mu \mathrm{g} / \mathrm{ml}$; goat lgG; R\&D Systems), anti-HMGB1 polyclonal antibody $(2 \mu \mathrm{g} / \mathrm{ml}$; rabbit IgG; Sigma-Aldrich), Glycyrrhizin, a specific HMGB1-inhibitor ${ }^{59}(10 \mu \mathrm{g} / \mathrm{ml}$; Calbiochem), or normal goat IgG ( $2 \mu \mathrm{g} / \mathrm{ml}$; Santa Cruz, Heidelberg, Germany) to the targets. In certain experiments, HMGB1 receptors RAGE, TLR-2 and TLR-4 were blocked on MSC, monocytes or iDC before adding the cells to the migration assay by pre-incubation with anti-human RAGE polyclonal antibody ( $20 \mu \mathrm{g} / \mathrm{ml}$, goat lgG), antihuman TLR-2 monoclonal antibody ( $2 \mu \mathrm{g} / \mathrm{ml}$, mouse IgG2B) or anti-human TLR-4 polyclonal antibody ( $10 \mu \mathrm{g} / \mathrm{ml}$, goat lgG) (all from R\&D Systems).

Detection of HMGB1 and HGF. HMGB1 and HGF levels in CM derived from vital $\mathrm{HT}-22$ and $\mathrm{HL}-1$ cells or harvested $12 \mathrm{~h}$ after induction of apoptosis or necrosis were determined using ELISA kits (Gentaur, Brussels, Belgium and Shino Test Corporation, Kanagawa, Japan, respectively) following the manufacturers' protocols.

To detect HGF and HMGB1 in HT-22 and HL-1 cells by immunofluorescence staining, cells were grown for $24 \mathrm{~h}$ on cover slips in 24-well plates, and apoptosis and necrosis were induced by staurosporine and $\mathrm{H}_{2} \mathrm{O}_{2}$ treatment, respectively. Vital (untreated), apoptotic and necrotic cells were fixed with $2 \%$ paraformaldehyde, permeabilized with $0.5 \%$ Triton X-100, and blocked with $1 \%$ BSA/PBS for $1 \mathrm{~h}$. Subsequently, cells were incubated overnight at $4^{\circ} \mathrm{C}$ with anti-HGF polyclonal antibody (10 $\mu \mathrm{g} / \mathrm{ml}$; goat Ig; R\&D Systems) or anti-HMGB1 polyclonal antibody $(2 \mu \mathrm{g} / \mathrm{ml}$; rabbit IgG; Sigma-Aldrich), washed with PBS+0.3\% Triton X-100+0.1\% Tween-20, and incubated with Alexa Fluor 488-tagged rabbit anti-goat lg or goat anti-rabbit lgG $(1: 100)$ for $2 \mathrm{~h}$ at room temperature. Followed by another washing step, nuclear staining was performed by incubation with TO-PRO-3 iodide for 15 min (final $1 \mu \mathrm{M}$; Molecular Probes, Darmstadt, Germany). Cells were washed again, coverslips were mounted with anti-fade fluorescence mounting medium and confocal microscopic analysis was performed using a LSM510 META confocal laser-scanning microscope and ZEN 2012 imaging software (Carl Zeiss Microlmaging, Jena, Germany).

Expression and release/secretion of HGF and HMGB1 as well as its respective association with apoptotic and necrotic cell death was also evaluated $24 \mathrm{~h}$ after induction of ischemia/reperfusion damage of the myocardium by transient ligation of the left anterior descending artery (see below). Non-infarcted hearts served as control group. Mice were killed $24 \mathrm{~h}$ after myocardial infarction and hearts were removed. Immunofluorescence stainings of paraffin-embedded cardiac sections were performed as described in the previous paragraph using anti-cleaved caspase 3 polyclonal antibody ( $5 \mu \mathrm{g} / \mathrm{ml}$; rabbit lgG; Abcam) or anti-cyclophilin A polyclonal antibody ( $5 \mu \mathrm{g} / \mathrm{ml}$; rabbit lgG; Abcam). Alexa Fluor 568-tagged donkey anti-rabbit lgG ( $1: 100$; Invitrogen) served as secondary antibody. Following the washing steps, cells 
were incubated with anti-HGF polyclonal antibody ( $10 \mu \mathrm{g} / \mathrm{ml}$; goat Ig; R\&D Systems) or anti-HMGB1 polyclonal antibody ( $2 \mu \mathrm{g} / \mathrm{ml}$; rabbit lgG; Sigma-Aldrich), washed and incubated with Alexa Fluor 488-tagged donkey anti-goat IgG or goat anti-rabbit IgG (both 1: 100; Invitrogen).

Flow cytometric detection of MET, RAGE, TLR-2 and TLR-4 expression. Expression of MET, RAGE, TLR-2 and TLR-4 on MSC, monocytes and iDC was evaluated by flow cytometry using MET (clone 95106, mouse lgG1; R\&D Systems), RAGE, TLR-2 and TLR-4-specific antibodies, respectively. Phycoerythrin-conjugated F(ab')2-goat-anti-mouse lgG+M (Beckman-Coulter, Krefeld, Germany) and $F\left(a b^{\prime}\right) 2$-donkey-anti-goat IgG (Jackson Laboratories, Hamburg, Germany) were used as secondary antibodies. Cells were analyzed on a FACS Canto flow cytometer using Diva software (BD Biosciences, Heidelberg, Germany).

Animals. Male C57BL/6J mice were obtained from Charles River (Sulzfeld, Germany) and were used for experiments at an age of 12 weeks. All animal experiments were performed in accordance with the Guide for the Care and Use of Laboratory Animals published by the US National Institutes of Health (NIH Publication No. 85-23, revised 1996), the guidelines for the use of living animals in scientific studies and the German law for the protection of animals, and were approved by the local authorities (Regierungspräsidium Tübingen, M 7/09).

Detection of macrophage and MSC infiltrates after myocardial ischemia/reperfusion. Transient ligation of the left anterior descending artery for $30 \mathrm{~min}$ (ischemia/reperfusion damage of the myocardium) was carried out as described previously. ${ }^{60}$ Mice were randomly assigned to receive either neutralizing anti-HMGB1 antibody ( $2 \mu \mathrm{g} / \mathrm{g}$ body weight; mouse IgG2b,k; Biolegend, London, UK; $N=3$ ) or isotype control antibody (equimolar; LEAF purified mouse lgG2b,k; Biolegend; $N=3$ ) by intravenous injection 10 min prior to ischemia. Mice were killed $24 \mathrm{~h}$ after induction of ischemia/reperfusion damage and hearts were removed.

Paraffin-embedded cardiac sections were stained with a streptavidin-biotinimmunoperoxidase method (StreptABComplex/HRP; Dako, Hamburg, Germany). Antibodies, anti-Mac-3 (5 $\mu \mathrm{g} / \mathrm{ml}$, rat lgG1,k; BD Biosciences), anti-p75 NGF receptor (CD271; $5 \mu \mathrm{g} / \mathrm{ml}$; mouse IgG; Abcam) and isotype control antibodies were used as primary antibodies. Corresponding secondary antibodies (Dako) were used according to standard protocols.

Statistical analysis. All data are presented as mean \pm S.E.M. for $N \geq 3$ unless stated otherwise. Statistical significance was determined with the Student's t-test using Graph Pad Prism software (GraphPad, San Diego, CA, USA).

\section{Conflict of Interest}

The authors declare no conflict of interest.

Acknowledgements. We would like to thank Heike Löfler and Ingrid Epple for excellent technical assistance. This work has been supported by a grant from the German Federal Ministry of Education and Research (BMBF) grant no. 01GN0951 (RM, WD, RVS), a grant from the German Heart Foundation/German Foundation of Heart Research grant no. F/19/13 (SV) and in part by the Deutsche Forschungsgemeinschaft (DFG) Klinische Forschergruppe KFO 274 'PlateletsBasic Mechanisms and Translational Implications' (MG).

1. Gregory CD, Pound JD. Cell death in the neighbourhood: direct microenvironmental effects of apoptosis in normal and neoplastic tissues. J Pathol 2011; 223: 177-194.

2. Nakamura T, Sakai K, Matsumoto K. Hepatocyte growth factor twenty years on: Much more than a growth factor. J Gastroenterol Hepatol 2011; 26(Suppl 1): 188-202.

3. Miyazawa K, Shimomura T, Naka D, Kitamura N. Proteolytic activation of hepatocyte growth factor in response to tissue injury. J Biol Chem 1994; 269: 8966-8970.

4. Neuss S, Becher E, Woltje M, Tietze L, Jahnen-Dechent W. Functional expression of HGF and HGF receptor/c-met in adult human mesenchymal stem cells suggests a role in cell mobilization, tissue repair, and wound healing. Stem Cells 2004; 22: 405-414.

5. Ono K, Matsumori A, Shioi T, Furukawa Y, Sasayama S. Enhanced expression of hepatocyte growth factor/c-Met by myocardial ischemia and reperfusion in a rat model. Circulation 1997; 95: 2552-2558.

6. Honda S, Kagoshima M, Wanaka A, Tohyama M, Matsumoto K, Nakamura T. Localization and functional coupling of HGF and c-Met/HGF receptor in rat brain: implication as neurotrophic factor. Brain Res Mol Brain Res 1995; 32: 197-210.
7. Bottaro DP, Rubin JS, Faletto DL, Chan AM, Kmiecik TE, Vande Woude GF et al. Identification of the hepatocyte growth factor receptor as the c-met proto-oncogene product. Science 1991; 251: 802-804.

8. Trapp T, Kogler G, El-Khattouti A, Sorg RV, Besselmann M, Focking M et al. Hepatocyte growth factor/C-met-axis mediated tropism of cord blood derived unrestricted somatic stem cells for neuronal injury. J Biol Chem 2008; 283: 32244-32253.

9. Vogel S, Trapp T, Borger V, Peters C, Lakbir D, Dilloo D et al. Hepatocyte growth factormediated attraction of mesenchymal stem cells for apoptotic neuronal and cardiomyocytic cells. Cell Mol Life Sci 2010; 67: 295-303.

10. Miyazawa T, Matsumoto K, Ohmichi H, Katoh H, Yamashima T, Nakamura T. Protection of hippocampal neurons from ischemia-induced delayed neuronal death by hepatocyte growth factor: a novel neurotrophic factor. J Cereb Blood Flow Metab 1998; 18: 345-348.

11. Nakamura T, Mizuno S, Matsumoto K, Sawa Y, Matsuda H. Myocardial protection from ischemia/ reperfusion injury by endogenous and exogenous HGF. J Clin Invest 2000; 106: 1511-1519.

12. Aoki M, Morishita R, Taniyama Y, Kida I, Moriguchi A, Matsumoto K et al. Angiogenesis induced by hepatocyte growth factor in non-infarcted myocardium and infarcted myocardium: up-regulation of essential transcription factor for angiogenesis, ets. Gene Ther 2000; 7 : 417-427.

13. Urbanek K, Rota M, Cascapera S, Bearzi C, Nascimbene A, De Angelis A et al. Cardiac stem cells possess growth factor-receptor systems that after activation regenerate the infarcted myocardium, improving ventricular function and long-term survival. Circ Res 2005; 97: 663-673

14. Heese O, Disko A, Zirkel D, Westphal M, Lamszus K. Neural stem cell migration toward gliomas in vitro. Neuro Oncol 2005; 7: 476-484.

15. Zhu G, Huang L, Song M, Yu Z, Wu X, Zhao X et al. Over-expression of hepatocyte growth factor in smooth muscle cells regulates endothelial progenitor cells differentiation, migration and proliferation. Int J Cardiol 2010; 138: 70-80.

16. Dominici M, Le Blanc K, Mueller I, Slaper-Cortenbach I, Marini F, Krause D et al. Minimal criteria for defining multipotent mesenchymal stromal cells. The International Society for Cellular Therapy position statement. Cytotherapy 2006; 8: 315-317.

17. Dharmasaroja P. Bone marrow-derived mesenchymal stem cells for the treatment of ischemic stroke. J Clin Neurosci 2009; 16: 12-20.

18. Nesselmann $\mathrm{C}, \mathrm{Ma} \mathrm{N}$, Bieback K, Wagner W, Ho A, Konttinen $\mathrm{YT}$ et al. Mesenchymal stem cells and cardiac repair. J Cell Mol Med 2008; 12: 1795-1810.

19. Khubutiya MS, Vagabov AV, Temnov AA, Sklifas AN. Paracrine mechanisms of proliferative, anti-apoptotic and anti-inflammatory effects of mesenchymal stromal cells in models of acute organ injury. Cytotherapy 2014; 16: 579-585

20. Uccelli A, Moretta L, Pistoia V. Mesenchymal stem cells in health and disease. Nat Rev Immunol 2008; 8: 726-736.

21. Ma S, Xie N, Li W, Yuan B, Shi Y, Wang Y. Immunobiology of mesenchymal stem cells. Cell Death Differ 2014; 21: 216-225.

22. Stros M. HMGB proteins: interactions with DNA and chromatin. Biochim Biophys Acta 2010; 1799: 101-113.

23. Wang $\mathrm{H}$, Bloom $\mathrm{O}$, Zhang $\mathrm{M}$, Vishnubhakat JM, Ombrellino M, Che $\mathrm{J}$ et al. HMG-1 as a late mediator of endotoxin lethality in mice. Science 1999; 285: 248-251.

24. Dumitriu IE, Baruah P, Valentinis B, Voll RE, Herrmann M, Nawroth PP et al. Release of high mobility group box 1 by dendritic cells controls $T$ cell activation via the receptor for advanced glycation end products. J Immunol 2005; 174: 7506-7515.

25. Andersson U, Tracey KJ. HMGB1 is a therapeutic target for sterile inflammation and infection. Annu Rev Immunol 2011; 29: 139-162.

26. Scaffidi $\mathrm{P}$, Misteli T, Bianchi ME. Release of chromatin protein HMGB1 by necrotic cells triggers inflammation. Nature 2002; 418: 191-195.

27. Bell CW, Jiang W, Reich 3rd CF, Pisetsky DS. The extracellular release of HMGB1 during apoptotic cell death. Am J Physiol Cell Physiol 2006; 291: C1318-C1325.

28. Kazama H, Ricci JE, Herndon JM, Hoppe G, Green DR, Ferguson TA. Induction of immunological tolerance by apoptotic cells requires caspase-dependent oxidation of highmobility group box-1 protein. Immunity 2008; 29: 21-32.

29. Venereau E, Casalgrandi M, Schiraldi M, Antoine DJ, Cattaneo A, De Marchis F et al. Mutually exclusive redox forms of HMGB1 promote cell recruitment or proinflammatory cytokine release. J Exp Med 2012; 209: 1519-1528.

30. Hori O, Brett J, Slattery T, Cao R, Zhang J, Chen JX et al. The receptor for advanced glycation end products (RAGE) is a cellular binding site for amphoterin. Mediation of neurite outgrowth and co-expression of rage and amphoterin in the developing nervous system. J Biol Chem 1995; 270: 25752-25761.

31. Park JS, Svetkauskaite D, He Q, Kim JY, Strassheim D, Ishizaka A et al. Involvement of tolllike receptors 2 and 4 in cellular activation by high mobility group box 1 protein. $J$ Biol Chem 2004; 279: 7370-7377.

32. Schiraldi M, Raucci A, Munoz LM, Livoti E, Celona B, Venereau E et al. HMGB1 promotes recruitment of inflammatory cells to damaged tissues by forming a complex with CXCL12 and signaling via CXCR4. J Exp Med 2012; 209: 551-563.

33. Chen GY, Nunez G. Sterile inflammation: sensing and reacting to damage. Nat Rev Immunol 2010; 10: 826-837.

34. Yang QW, Wang JZ, Li JC, Zhou Y, Zhong Q, Lu FL et al. High-mobility group protein box-1 and its relevance to cerebral ischemia. J Cereb Blood Flow Metab 2010; 30: 243-254.

35. Mitola S, Belleri M, Urbinati C, Coltrini D, Sparatore B, Pedrazzi M et al. Cutting edge: extracellular high mobility group box-1 protein is a proangiogenic cytokine. J Immunol 2006; 176: 12-15. 
36. Meng E, Guo Z, Wang H, Jin J, Wang J, Wu C et al. High mobility group box 1 protein inhibits the proliferation of human mesenchymal stem cells and promotes their migration and differentiation along osteoblastic pathway. Stem Cells Dev 2008; 17: 805-813.

37. Chavakis E, Hain A, Vinci M, Carmona G, Bianchi ME, Vajkoczy P et al. High-mobility group box 1 activates integrin-dependent homing of endothelial progenitor cells. Circ Res 2007; 100: 204-212.

38. Buja LM, Entman ML. Modes of myocardial cell injury and cell death in ischemic heart disease. Circulation 1998; 98: 1355-1357.

39. Quirici N, Soligo D, Bossolasco P, Servida F, Lumini C, Deliliers GL. Isolation of bone marrow mesenchymal stem cells by anti-nerve growth factor receptor antibodies. Exp Hematol 2002; 30: 783-791.

40. Goldstein RS, Gallowitsch-Puerta M, Yang L, Rosas-Ballina M, Huston JM, Czura CJ et al. Elevated high-mobility group box 1 levels in patients with cerebral and myocardial ischemia. Shock 2006; 25: 571-574.

41. Campana L, Bosurgi L, Bianchi ME, Manfredi AA, Rovere-Querini P. Requirement of HMGB1 for stromal cell-derived factor-1/CXCL12-dependent migration of macrophages and dendritic cells. J Leukoc Biol 2009; 86: 609-615.

42. Yang $D$, Chen $Q$, Yang H, Tracey KJ, Bustin M, Oppenheim JJ. High mobility group box-1 protein induces the migration and activation of human dendritic cells and acts as an alarmin. $J$ Leukoc Biol 2007; 81: 59-66.

43. Ciucci A, Gabriele I, Percario ZA, Affabris E, Colizzi V, Mancino G. HMGB1 and cord blood: its role as immuno-adjuvant factor in innate immunity. PLoS One 2011; 6: e23766.

44. Dumitriu IE, Bianchi ME, Bacci M, Manfredi AA, Rovere-Querini P. The secretion of HMGB1 is required for the migration of maturing dendritic cells. J Leukoc Biol 2007; 81: 84-91.

45. Lotfi R, Eisenbacher J, Solgi G, Fuchs K, Yildiz T, Nienhaus C et al. Human mesenchymal stem cells respond to native but not oxidized damage associated molecular pattern molecules from necrotic (tumor) material. Eur J Immunol 2011; 41: 2021-2028.

46. Tamai K, Yamazaki T, Chino T, Ishii M, Otsuru S, Kikuchi Y et al. PDGFRalpha-positive cells in bone marrow are mobilized by high mobility group box 1 (HMGB1) to regenerate injured epithelia. Proc Natl Acad Sci USA 2011; 108: 6609-6614.

47. Degryse B, Bonaldi T, Scaffidi P, Muller S, Resnati M, Sanvito $F$ et al. The high mobility group (HMG) boxes of the nuclear protein HMG1 induce chemotaxis and cytoskeleton reorganization in rat smooth muscle cells. J Cell Biol 2001; 152: 1197-1206.

48. Ranzato E, Patrone M, Pedrazzi M, Burlando B. Hmgb1 promotes wound healing of $3 T 3$ mouse fibroblasts via RAGE-dependent ERK1/2 activation. Cell Biochem Biophys 2010; 57 : 9-17.
49. Kurz SM, Diebold SS, Hieronymus T, Gust TC, Bartunek P, Sachs M et al. The impact of c-met/scatter factor receptor on dendritic cell migration. Eur J Immunol 2002; 32: 1832-1838.

50. Beilmann M, Vande Woude GF, Dienes HP, Schirmacher P. Hepatocyte growth factorstimulated invasiveness of monocytes. Blood 2000; 95: 3964-3969.

51. Dai S, Sodhi C, Cetin S, Richardson W, Branca M, Neal MD et al. Extracellular high mobility group box-1 (HMGB1) inhibits enterocyte migration via activation of Toll-like receptor-4 and increased cell-matrix adhesiveness. J Biol Chem 2010; 285: 4995-5002.

52. Bauer EM, Shapiro R, Billiar TR, Bauer PM. High mobility group Box 1 inhibits human pulmonary artery endothelial cell migration via a Toll-like receptor 4- and interferon response factor 3-dependent mechanism(s). J Biol Chem 2013; 288: 1365-1373.

53. Apetoh L, Ghiringhelli F, Tesniere A, Obeid M, Ortiz C, Criollo A et al. Toll-like receptor 4-dependent contribution of the immune system to anticancer chemotherapy and radiotherapy. Nat Med 2007; 13: 1050-1059.

54. Liu G, Wang J, Park YJ, Tsuruta Y, Lorne EF, Zhao X et al. High mobility group protein-1 inhibits phagocytosis of apoptotic neutrophils through binding to phosphatidylserine. $\mathrm{J}$ Immunol 2008; 181: 4240-4246.

55. Waterman RS, Tomchuck SL, Henkle SL, Betancourt AM. A new mesenchymal stem cell (MSC) paradigm: polarization into a pro-inflammatory MSC1 or an Immunosuppressive MSC2 phenotype. PLOS One 2010; 5: e10088.

56. Liotta $F$, Angeli $R$, Cosmi L, Fili L, Manuelli $C$, Frosali $F$ et al. Toll-like receptors 3 and 4 are expressed by human bone marrow-derived mesenchymal stem cells and can inhibit their T-cell modulatory activity by impairing Notch signaling. Stem Cells 2008; 26: 279-289.

57. Opitz CA, Litzenburger UM, Lutz C, Lanz TV, Tritschler I, Koppel A et al. Toll-like receptor engagement enhances the immunosuppressive properties of human bone marrow-derived mesenchymal stem cells by inducing indoleamine-2,3-dioxygenase-1 via interferon-beta and protein kinase R. Stem Cells 2009; 27: 909-919.

58. Rapp M, Ozcan Z, Steiger HJ, Wernet P, Sabel MC, Sorg RV. Cellular immunity of patients with malignant glioma: prerequisites for dendritic cell vaccination immunotherapy. $J$ Neurosurg 2006; 105: 41-50.

59. Mollica L, De Marchis F, Spitaleri A, Dallacosta C, Pennacchini D, Zamai M et al. Glycyrrhizin binds to high-mobility group box 1 protein and inhibits its cytokine activities. Chem Biol 2007; 14: $431-441$.

60. Borst O, Ochmann C, Schonberger T, Jacoby C, Stellos K, Seizer P et al. Methods employed for induction and analysis of experimental myocardial infarction in mice. Cell Physiol Biochem 2011; 28: 1-12

\section{Supplementary Information accompanies this paper on Cell Death and Differentiation website (http://www.nature.com/cdd)}

